\title{
Geological framework and mineral occurrences in the Georgia segment Eastern Greater Caucasus
}

\author{
Faculty of Natural Sciences and Engineering, Ilia state University, Tbilisi, Georgia. \\ E-mail: ${ }^{1}$ okrostsvari@gmail.com; ${ }^{2}$ nona.gagnidze@iliauni.edu.ge; ${ }^{3}$ giorgi.boichenko@iliauni.edu.ge
}

(Received: 01/08/2015; Accepted 01/12/2015)

DOI:10.18814/epiiugs/2016/v39i3/99770

The eastern part of the Caucasus orogen, termed the Georgian segment, is mainly underlain by highly deformed Lower-Middle Jurassic shales, sandstones, and volcaniclastic rocks, and cut by numerous intrusive bodies of various compositions. All units contain a variety of mineral deposit types and their surrounding zones of hydrothermal alteration. Detailed geological and metallogenic research, after 30 years stagnation, has led to important new information regarding the evolution of this region. Three main stages of magmatic activity are now clearly distinguished. The oldest magmatism comprises early Jurassic events, related to extensional tectonism, with volcanism and subvolcanic plutonism that ranged from rhyolitic, through dacitic and andesitic, and to basaltic. Additional extensional processes (in Bajocian times) were characterized by intrusion of a gabbro and diorite dike system into slightly older late Early Jurassicearly Middle Jurassic formations. The final magmatic event was associated with Middle Jurassic folding and uplift during which multiphase diorite plutons were emplaced. Intense hydrothermal activity related to this latest magmatism was responisble for important polymetallic mineralization including more than 100 historically recognized outcropping occurrences. A detailed study of 11 of the more significant of these occurrences has indicated anomalous concentrations of base metals as well as gold, thorium, yttrium, cobalt, cadmium, and bismuth. In addition, several new and potentially significant mineral occurrences were discovered, including two designated here as Gelia and Lechuri.

\section{Introduction}

In the past ten years, the global increase in consumption of industrial and metallic minerals has been ever increasing due to modernization and the higher degree of urbanization of much of the world. It is obvious that new mineral discoveries are needed to meet global demands as well as improved recovery and brownfields exploration in areas of previously recognized deposits. These are essential as the world continues to modernize.

Recognizing these challenges, we have studied known mineralized systems and described new metal-rich areas in the eastern Greater Caucasus region, located within the Georgia Republic. More than 100 , historic, pyrite-pyrrhotite and copper-polymetallic dominant mineralized occurences of varied size are recognized in this region, and they include disseminations, veins, and massive sulfide bodies. The significance of our research on the mineral occurrences of the region is particularly well justified because in neighboring Azerbaijan, along the southern slope of the Greater Caucasus, important stratiform pyrite-copper-polymetallic deposits, containing economic precious metals (e.g., Katsdag, Filizchay, and Katekh), were discovered in the 1960s in rocks that continue into the Georgia Republic. Also, almost at the same time, the Kizil Dere copper-pyrrhotite deposit, on the northern slope of the Greater Caucasus in Dagestan (Russian Federation), was put into production. Mineralization is represented by pyritic, Zn-pyritic and Cu-pyrrhotite ores (Kekelia et al., 2004). Subsequently in the 1970s, after discovery of the deposits in Azerbaijan and Dagestan, a large-scale geological exploration program for non-ferrous metals was carried out in the Georgian part of the Greater Caucasus. However, despite the high favorability for the presence of new mineral resources in similar geologic enviornments, the previous programs were not successful in identifying important, new and potentially viable deposits in Georgia.

In the eastern Greater Caucasus segment, after almost 30 years with relatively no metallogenic research, we carried out new geological work to address potential resource favorability. In particular, our work included a more detailed geological reconstruction of the region, defining magmatic and post-magmatic hydrothermal events and examining the ore occurrences of the region. Analysis of the relevant data allowed us to make essential corrections to the pre-existing geological understanding of the region, and, in particular, important new points on regional metallogeny were demonstrated.

\section{Field sampling and analytical methods}

Field work was carried out in the limits of Kakheti region and was based on classical geological methods including mapping at 1:25,000 scale. During geological field work more than 200 samples 
were collected for petrographic study and, about 700 samples were collected for geochemical anlayses. In addition 12 samples of magmatic rocks were selected for isotopic dating. Geochemical samples, each about 3-4 kg, were taken from individual locations, although larger 6-7 kg samples were collected for the geochronology work. Major element analyses, and petrographic and mineralogical description of rocks were carried out at the geological laboratory of Ilia State University in Tbilisi. Isotopic dating of zircons (U-Pb method) and Trace element analyses were carried out at the Geology Department of Taiwan National University and at the Acme Labs in Vancouver, Canada, using ICP-MS methods. Additional analyses were also done at the laboratory of Caucasus Mining Group Gold Ltd (Madenueli, Georgia) by atomic absorption spectrometry.

\section{Geological framework}

The Caucasus orogen was formed as a result of a Phanerozoic collision between the southern continental margin of the Eurasian plate and the Arabian plate, and it extends for more than $1200 \mathrm{~km}$ from the Caspian to the Black Sea. Three major units are distinguished in the Caucasus, which are traditionally called the Greater and Lesser Caucasian mobile belts and the inner Caucasian microplate. The Greater Caucasus Mountains are the northernmost part of the Caucasus orogen, with terranes that are accreted to the south margin of the Eurasian continent (Gamkrelidze, 1997). It consists of a complexly folded series of nappes. The two major sequences resulting from its construction are distinguished as the pre-Mesozoic crystalline basement and Mesozoic-Cenozoic sedimentary and volcanicsedimentary cover (Gamkrelidze, 1986; Okrostsvaridze, Tormay, 2013).

Based upon geophysical surveys in the region, the eastern Greater Caucasus sedimentary cover is located over thin crust of a transitional type (Fig. 1). We agree with the interpretation of the deep fault zone in the region, along which magma was transporting from the mantle (Philip et al., 1989; Rebaï et al., 1993), and it is well supported by the magmatic history of the region as described below.

The Eastern Greater Caucasus in Georgia, which is approximately 25-40 km in width, can be traced for about $125 \mathrm{~km}$, from the IoriAlazani watershed in the east to the Mazim-Chay River valley near the Azerbaijan border in. Its northern border runs along the southern boundaries of Dagestan and Chechnya, and, to the south, it is separated from the Alazani River valley by a regional fault system. The entire area covers approximately $3900 \mathrm{~km}^{2}$.

Our study area includes two regions of eastern Georgia: (1) Kakheti (Fig. 2), located on the southern slope of the Greater Caucasus and (2) Tusheti, on the northern slope. On the southern slope the area comprises the watersheds of the Alazani River and its tributaries including the Makhvali, Stori, Didi Khevi, Lopota and other rivers (Fig. 3) of the Kakheti region. The northern slope of the range is dominated by the Tusheti Alazani River and its tributaries in the Tusheti region. The sedimentary cover of both slopes is generally similar and is mainly represented by highly folded, Lower-Middle Jurassic terrigenous schists, shales, and sandstones with intercalated dacite-andesite-basalt volcanic formations. Numerous postaccretionary intrusive bodies of different composition and size were emplaced into the sedimentary cover rocks. Nearly all rock units have experienced extensive faulting, brecciation, hydrothermal alteration, and metallic mineral deposition.

\section{Sedimentary cover}

The sedimentary cover of the eastern Greater Caucasus in the Georgian segment is mainly represented by a thick series of LowerMiddle Jurassic shales and sandstones, with thinner sequences of volcanogenic-sedimentary formations. The series of sedimentary rocks is exposed within a regional anticline structure, which is traced in a NW-SE direction and is overturned to south (see cross section on Fig. 3). These rocks were deposited as a result of major rifting and subsidence in the Paleozoic basement, which resulted in formation of a marginal sea environment. Some small fragments of this basement outcrop on the southern slope in deeply cut canyons.

In the eastern Greater Caucasus, the oldest sedimentary rocks dated by fauna are Pliensbachian age (ca.189-183 Ma) shales and clay-rich shales, which contain interlayers of fine-grained sandstones, siltstones, and rarely carbonate rocks (see Figure 3). Pliensbachian ammonites are observed in the calcareous sandstones (Topchishvili, 1996). Also subalkaline basalt sheets are present in the suite. The total thickness of the suite is approxi-mately $1000 \mathrm{~m}$.

The suite of Pliensbachian rocks gradually grades upward into rocks of the Toarcian sedimentary complex (ca.183$174 \mathrm{Ma}$ ); this section, dated by fauna, is mainly represented by flysch and sandstones. These sediments can be traced for almost the entire length of the Kakheti region, with total thickness of about 1100 m. Rocks of the Aalenian (ca.175$171 \mathrm{Ma}$ ) Stage, which conformably overlie the rocks of the Toarcian complex, are also dated by fauna. The suite is represented by fine-grained sandstones, argillites, and black shales. In some areas, andesite and basalt sheets and associated tuffs are exposed. The total thickness of the suite is determined to be about 800$900 \mathrm{~m}$. The youngest rocks in the sedimentary series are Oxfordian (ca. 163$157 \mathrm{Ma}$ ) clastic limestones and Lower Figure 1. Simplified lithospheric cro
according to Phillips and others (1989). 


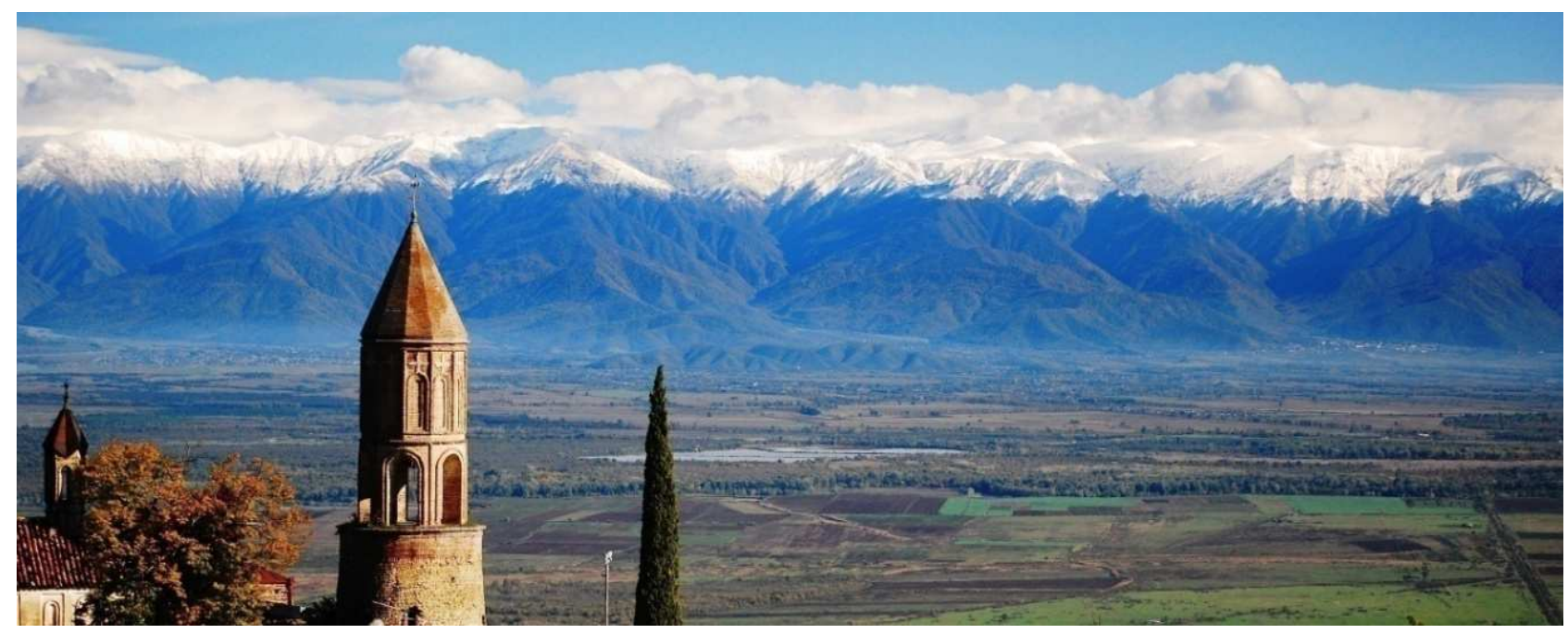

Figure 2. General view of the eastern Greater Caucasus, Kakheti region. The Alazani basin is in the middle distance.

Cretaceous sandstones, turbidites and limestones, preserved locally at the boundary (see Fig. 1) between the Greater Caucasus southern slope and the Alazani basin (Akimidze, 2010).

The sedimentary cover in many areas of the study area is intensely deformed with widespread development of cataclasites, mylonitization, hydrothermal alteration, and sulfide mineralization. These features are well developed in the Stori River canyon, where the hydrothermal alteration can be traced for a distance of $4 \mathrm{~km}$. Because of the intense alteration, the exact precursor sedimentary rocks at this location are usually difficult to identify. In the highly altered section of the canyon, many of the sedimentary rocks have been transformed to albite-quartz-epidote-chlorite and quartz-sericitechlorite assemblages. These altered rocks almost always contain some pyrite, rare pyrrhotite, and very rare chalcopyrite (Fig. 4).

\section{Magmatism}

Magmatic rocks are very significant in the geologic evolution of the Kakheti segment of the eastern Greater Caucasus. Mesozoic subvolcanic and intrusive bodies of different compositions have played an important role in formation of the hydrothermal alteration of the sedimentary cover and deposition of the sulfide mineral occurrences. However, small blocks of Paleozoic basement are also exposed in the Stori River canyon; these are in tectonic contact with the Jurassic sediments. We dated cataclastically deformed granite porphyry that comprises some of a fragmented block, by $\mathrm{U}-\mathrm{Pb}$ on zircons and a resulting age of $312 \pm 3$ Ma was obtained.

Our data suggest that the first major post-Paleozoic magmatic activity in the region began in Early Jurassic time. It was linked to basement extension and rifting processes, and its products include quartz porphyries, plagiogranite porphyries, and granite porphyries that intrude the shales and sandstones of Early Jurassic age. Pyroclastic rocks of rhyolite and dacite composition are widespread in the Early Jurassic sediments. They represent the extrusive equivalents of the above noted subvolcanic bodies. In some locations, felsic magmatic rocks are dominant over the sedimentary rocks, such as in the Speroza Mountains and in outcrops alongs the Lopota River (see Fig. 3). During the last stage of this magmatic activity, thick basalt sheets were formed, which are mostly represented by lava-breccias and pillow lavas.
The second major magmatic event in the region is marked in Bajocian (170-168) (Akimidze et al., 1980; Akimidze, 2010), which is related to further extension of the newly formed ocean basin crust. Products of this magmatic activity are shallowly formed basic intrusions, which were emplaced into rocks of the Lower Jurassic Aalenian Stage. They appear as gabbro-diabase and diabase porphyry dike systems. These dikes have thickness up to $0.3-30 \mathrm{~m}$ at the modern erosion level, and can be traced for tens to hundreds of meters along strike. They are commonly localized along fault zones and are widely distributed. Based upon our petrographic studies, these mafic rocks are mainly represented by hornblende- and augite- diabases in which hornblende has widely replaced pyroxene. As for the impact of the diabase dikes on their surrounding wallrocks, as well as regarding their ore-forming potential, there is no evidence of any associated important hydrothermal activity.

The third major period of magmatic activity in the region was during Bathonian time (ca. 168-166 Ma), which, according to our field observations, is represented by multi-phase plutonic bodies, as evidenced by of fragments of silicified diabase dikes contained in younger magmatic rocks. Only a limited amount of these plutonic bodies outcrop, as they have yet to be widely exposed by erosion (Fig. 5). These plutonic rocks are mainly composed of plagioclase, hornblende, quartz, epidote, chlorite, sulfide minerals (pyrite, chalcopyrite, pyrrhotite, sphalerite), sphene, and zircon. The REE distribution patterns of these intrusives show that the main magmatic mass experienced relatively little fractionation. However, in the exposed apical parts of these bodies, multi-phase stocks are present, which have average felsic compositions. The mineralogy of the felsic rocks is simple and they are generally composed of quartz, plagioclase, and local minor potash feldspar and sericite. Our fieldwork has shown that the intense hydrothermal alteration and associated mineralization are genetically related to this last stage of magmatic activity and felsic differentiation.

Summarizing the data on magmatism in the eastern Greater Caucasus region of Georgia, there are clearly three major Mesozoic stages. The first magmatic activity was associated with crustal subsidence, extension, and rifting in Early Jurassic. Associated magmatic rocks varied in compostion from rhyolite, to dacite, and through to andesite and basalt. The second significant magmatic event linked to the extension of the newly formed crust and deposition of 


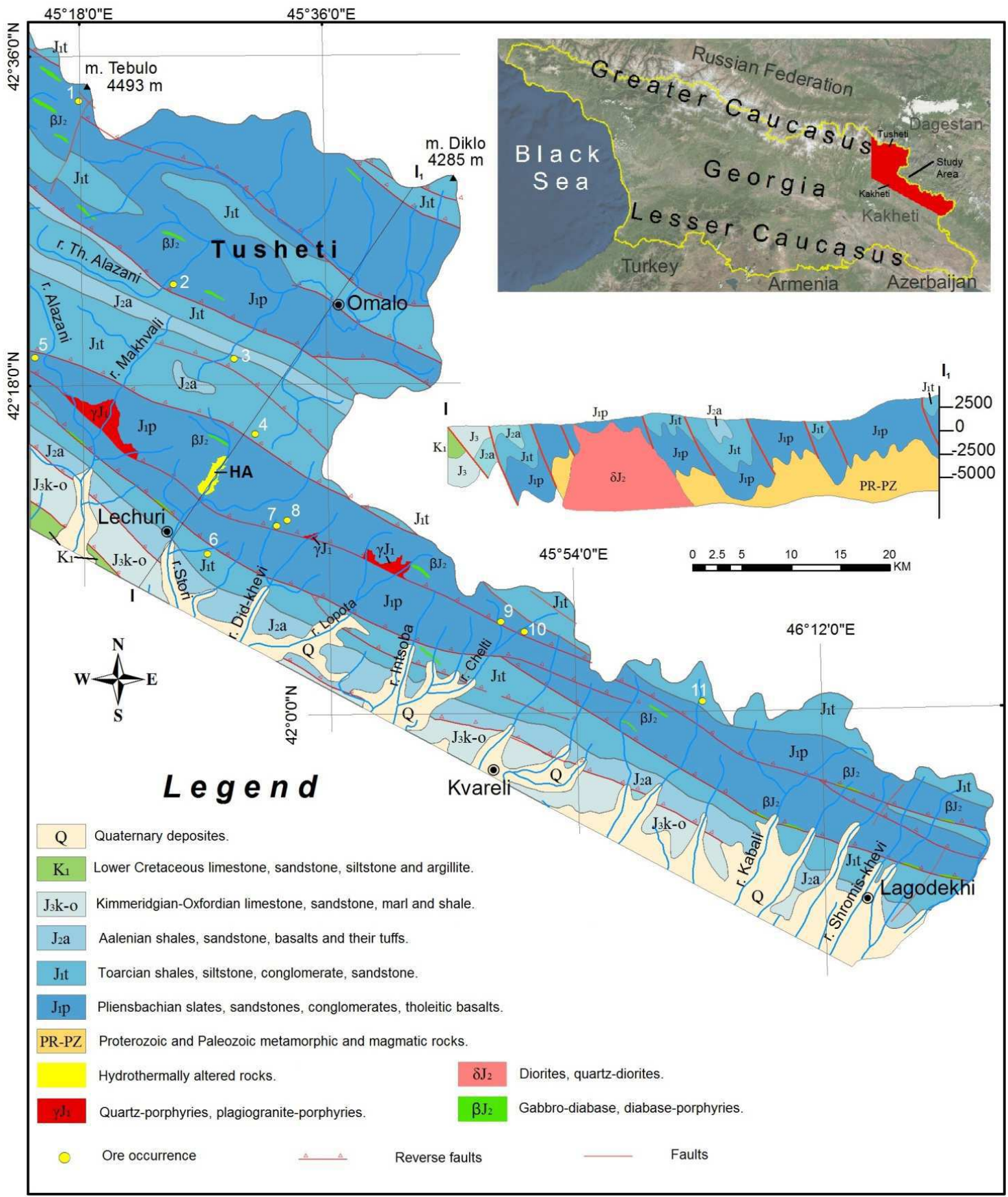

Figure 3. Geological Map of the eastern Greater Caucasus Georgian Segment. Main mineral occurrences: 1- Tebulo; 2- Ilurta; 3- Satskhvre Khorkhi; 4- Abano; 5- Quachadala; 6-Stori; 7-Artana orefield: Samchedlo, Englisuri; 8-Loduani; 9- Chelti, 10- Shorokhevi; 11- HA-Stori hydrothermal alteration zone.

Aalenian sediments; this period was characterized by basic intrusions and formed gabbro-diabase dike systems. The third period of magmatic activity is associated with folding and uplift in Bathonian time, when multiphase dioritic plutons intruded the sedimentary cover, which caused the intense hydrothermal alteration of the country rocks, including extensive areas of propylitic and phyllic alteration, and mineralization.

\section{Mineral Occurrences}

Research on the mineral occurrences in the eastern part of the
Greater Caucasus in Georgia began in the early 1900s. Today, in our studied area, more than 100 sulfide-bearing mineral occurrences (Kharashvili, 1964; Kuchava et al., 1983; Okrostsvaridze et al., 2012) are recognized (see Figure 3). These lode occurences include disseminations, veins/veinlets, or bodies of massive sulfide. In places, disseminations and veins may grade into more massive sulfide bodies. Metallic mineralization is accompanied by hydrothermal alteration and silicification of wallrocks, during which quartz-sericite-chlorite and albite-quartz-epidote-chlorite-carbonate assemblages are formed. Later fracturing of these altered rocks has led to deposition of quartzpyrite-pyrrhotite, quartz-chalcopyrite, and relatively late quartz- 


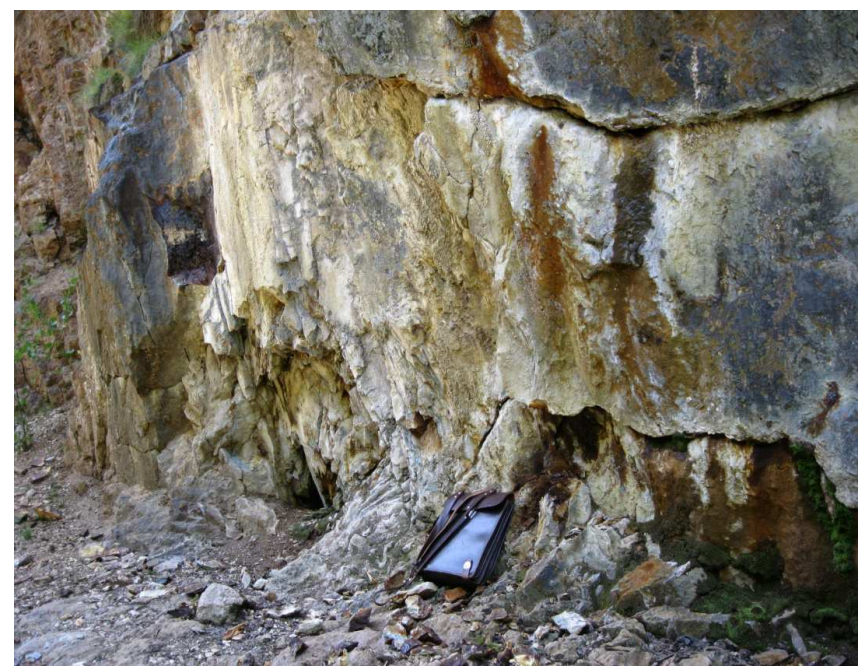

Figure 4. Crushed and hydrothermaly altered Early Jurassic shales, Stori canyon.

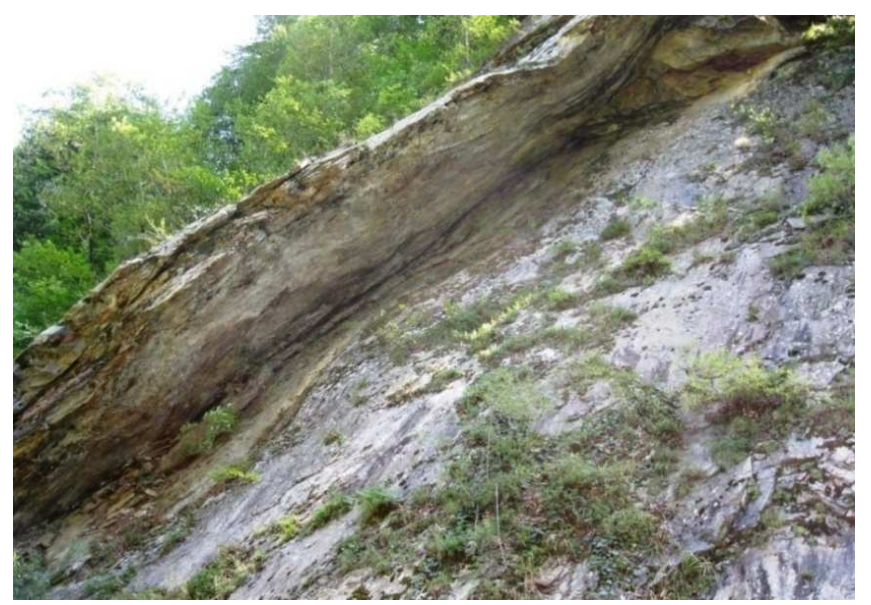

Figure 5. Contact of quartz-diorite body with Pliensbachian shales, southern Stori River canyon.

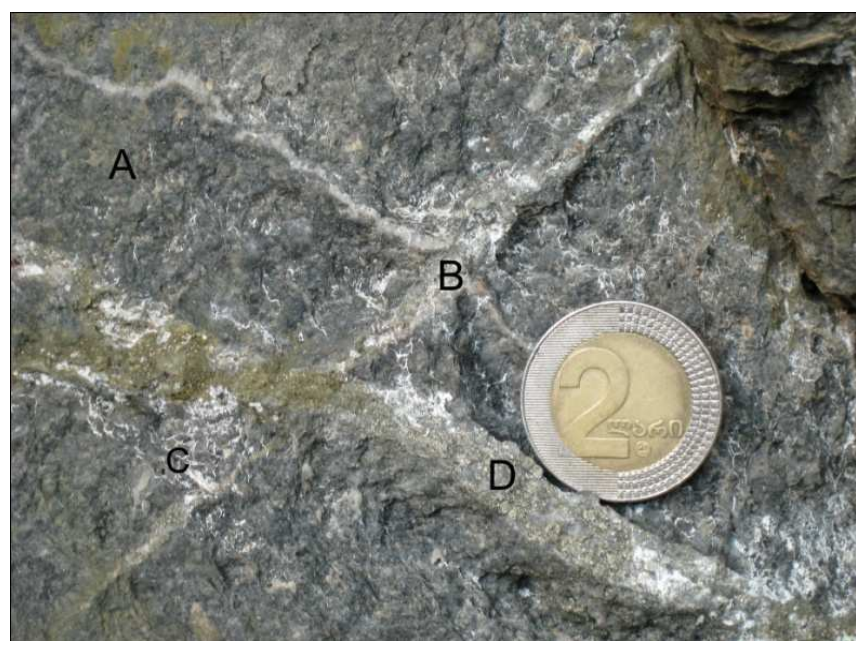

Figure 6. Silicified and ore mineralized Pliensbachian shale, Stori River canyon. A- silicified and carbonatized shale; B- quartz vein, C-carbonate veinlets, D - quartz-pyrite-pyrrhotite vein. calcite-polymetallic assemblages from metal-bearing hydrothermal fluids (Fig. 6).

We have studied in detail the historic mineral occurrences at Tebulo, Ilurta, Satskhvre Khorkhi, Abano, Quachadala, Artana, Loduani, Chelti, and Shorokhevi (see Fig. 3). In addition to these localities, we conducted the first scientific observations and studies of several recently discovered mineral occurrences. These include those in a large hydrothermally altered zone in the Stori River district which we have designated as the Gelia, Bendena and Thorium zones (see HA on Fig. 3). Also near the village of Lechuri, we examined what we refer to as the newly defined Lechuri mineral occurrence. In this present paper, we characterize below, some of our important new observations on the metallogeny that may indicate significant targets for detailed exploration.

Stori district. The Stori district (see locality 6: Fig. 3) represents a broad area of altered rocks within the Stori River canyon. The zone is developed on the southern slope of the Greater Caucasus in the Stori River canyon and was traced along strike for about $4 \mathrm{~km}$ until reaching the Abano bridge over the Stori River. The zone is cut by the Pshaveli-Omalo road, which provided access for this study (Fig. 7) .

The hydrothermal alteration in the district is developed within the Pliensbachian shales and sandstones. The altered rocks mainly comprise quartz-sericite-chlorite and quartz-albite-chlorite-epidote assemblages, which also contain abundant pyrite, indicating that the fluids were rich in iron and sulfur. These rocks are easily distinguished because of their reddish, yellow, and grey colors (see Fig. 4). We interpret the alteration to represent typical phyllic and propylitic assemblages that tend to develop around large-scale porphyry $\mathrm{Cu} \pm \mathrm{Au}$, Mo mineral systerms (Ridley, 2013).

More than 200 rock samples collected along the the length of the Stori district were analyzed for gold by ICP-MS, but results did not generally indicate any significant precious metal targets. However, in the northern part of the district, four zones that are

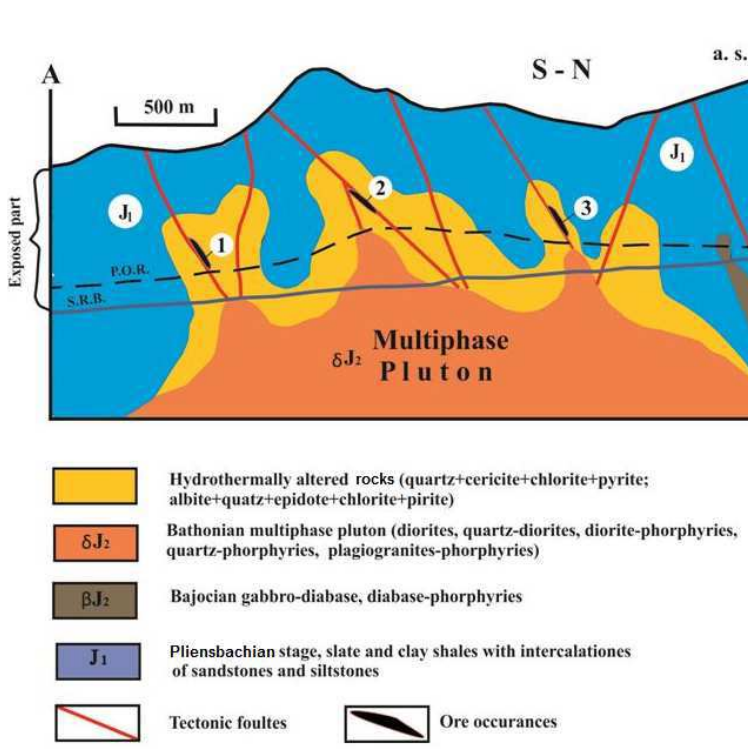

Figure 7. Schematic cross section (A-B) of the Stori canyon hydrothermal alteration zone. (A=N 42 $12^{\prime} 968^{\prime \prime}, E 4^{\circ} 29^{\prime} 079^{\prime \prime}$; $\left.B=N 42^{\circ} 13^{\prime} 953^{\prime \prime}, E 45^{\circ} 29^{\prime} 079^{\prime \prime}\right)$. Mineral occurrences:1Bendena, 2-Gelia, 3-Thorium. (P.O.R.- Phshaveli-Omalo road; S.R.B.-Stori River bed). 
several tens of meters thick and parallel to the general Caucasian trend contained 10-94 ppb Au, concentrations that exceed normal background levels for most sedimentary rocks. The assay results showed as much as $66,94,68$, and $87 \mathrm{ppb}$ Au in localities 1 through 4 (see Fig. 3).

Three extremely anomalous occurrences, termed Bendena, Gelia and Thorium, were identified. Although there might be more of such occurrences, accessibility issues prevented study of many altered locations within the Stori River valley. Recent publications exist on the Stori Thorium occurrence (Okrostsvaridze et al., 2012) thus only a summary of the existing information is given in this paper. The thorium occurrence is located in the northern part of the district. It is characterized by high concentrations of thorium in association with carbonate-quartz-plagioclase veins, which cut Pliensbachian shales; these are about $20-30 \mathrm{~cm}$ in thickness. Concentrations of Th in these veins vary from 31 to $3882 \mathrm{ppm}$. In addition to thorium, anomalous $\mathrm{Bi}$ (57- $4806 \mathrm{ppm})$ and Y (75 - $4345 \mathrm{ppm})$ are also recognized in the mineralized zone. These types of thorium deposits are known in many regions of the world, such as described by Staatz (1974) in many locations in the USA.

The Gelia mineral occurrence is exposed in the central part of the Stori district, in the Gelia ravine, and is located about $200 \mathrm{~m}$ above the main road (Fig. 8). It includes a copper-rich pyrrhotitechalcopyrite-quartz vein formed within a wide fault zone and is surrounded by haloes of quartz-sericite-chlorite alteration. The vein and associated fault zone ranges in thickness from 5-10 m and can be traced continuously towards the ravine for $80-90 \mathrm{~m}$. Beyond the ravine, due to a rocky cornice, tracing of the vein is not possible, but there is a $250-\mathrm{m}$-long section of intensely oxidized rock, which suggests additional $\mathrm{Fe}-\mathrm{Cu}$ mineralization at depth.

The Gelia vein, which is clearly the product of a metalliferous hydrothermal event, was studied in detail. The main sulfide mineral in the vein is pyrrhotite, with subordinate chalcopyrite, pyrite, and arsenopyrite; in places, the sulfides are present as large masses. A range of metals was measured for 45 samples of the massive quartzpyrrhotite-chalcopyrite mineralization from the vein by ICP-MS methods. The range of concentrations are as follows: $950-2660 \mathrm{ppm}$ $\mathrm{Cu}, 11$ - 33 ppm Pb, 25 -35 ppm Zn, 1500 - 6400 ppm As, 124 -295 ppm Co, and $25-35 \% \mathrm{Fe}$. Gold and silver were generally not detected in the massive ores, although two samples from vein selvages did contain 1.41 and $4.56 \mathrm{ppm} \mathrm{Au}$. The results from the Gelia vein chemical analyses indicate consistent enrichments in $\mathrm{Fe}, \mathrm{Cu}$, and $\mathrm{As}$,

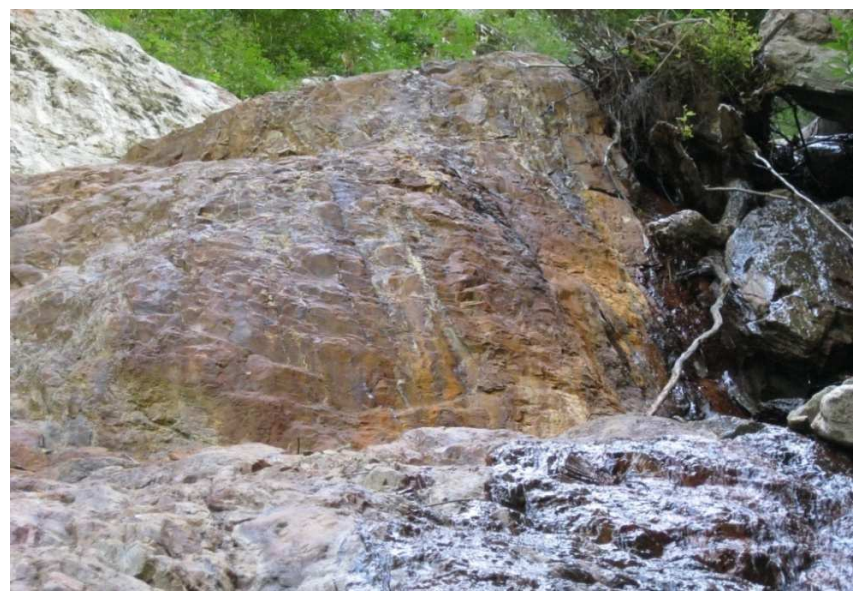

Figure 8. View of Gelia quartz-pyrrhotite-chalcopyrite vein. with some potential for Au mineralization. This element suite is consistent with that formed in hydrothermally altered zones surrounding porphyry deposits (Ridley, 2013).

As for the Bendena occurence, compared with the central and northern parts of the Stori district, metal concentration is almost the same but it is a less mineralized occurence. The Au concentration here was detected as $\sim 0.4 \mathrm{ppm}$.

Artana district. There are ten known mineral occurences within the Aratana district (see \#7; Fig. 3). Among these, the best studied occurrences are Samchedlo and Englisuri.

The mineralized vein at Samchedlo is situated in the rocky cornices of the Okhotis-Tskali River valley, $12 \mathrm{~km}$ north of the village of Artana (see Fig. 3). The vein is localized in a fault gouge zone, with a general strike parallel to Caucasus Range and a shallow dip of $20-30^{\circ}$. The country rocks are those of the Pliensbachian shales. The thickness of the mineralized vein is $2-2.5 \mathrm{~m}$, and can be traced along strike for about $500-550 \mathrm{~m}$. The central part of the vein contains massive chalcopyrite and pyrrhotite and is highly brecciated. In addition to these main sulfide minerals, small amounts of galena, sphalerite, ilmenite, and cobaltine are present.

During our research at Samchedlo we collected and analyzed 38 samples by ICP-MS. Resulting data for the massive sulfides indicated 1.40 - 3.54\% Cu, 19.6 - 61.4\% Fe, 17 - 21 ppm Pb, 173 - 610 ppm Zn, 118 -1040 ppm Co, 8 - 22 ppm Cd,15 - 50 ppm Bi, and 2 - 4 ppm $\mathrm{Ag}$. In the massive chalcopyrite-pyrrhotite mineralization, anomalous concentrations of gold were consistently detected at values between 0.32 and $1.31 \mathrm{ppm}$.

The discordant vein at Englisuri is located on the rocky cornices of the Okhotis-Tskali River valley, and is about $1.5 \mathrm{~km}$ from the Samchedlo mineralized area. It is also situated in a fault gouge that is parallel to the general trend of the range and dips about $50^{\circ}$, with thickness of 4.5-5.0 m. The vein and associated fault zone occurs in brecciated, chloritized, and silicified Pliensbachian shales. In the middle of the alteration zone, the sulfide-rich vein is $1.4-1.8 \mathrm{~m}$ in thickness. It appears as pyrrhotite-chalcopyrite in lenses, pods, and quartz veinlets, with also a small amount of pyrite, galena, and sphalerite. A 38-m-long adit intersects the mineralization. Along the southern side of the vein, intense silicification and malachite staining are evident in an area of older adits developed by British prospectors.

Our data for the vein at Englisuri was collected from 42 samples that were analyzed by ICP-MS. Resulting data for the massive mineralization ranged from $1.09-5.14 \% \mathrm{Cu}, 16.4-61.4 \% \mathrm{Fe}, 6-44$ ppm Pb,140 - 8540 ppm Zn, 118 -1040 ppm Co, 8 - 22 ppm Cd,19 75 ppm Bi,12 - 28 ppm As, and 2 - 4 ppm Ag. In a selvage of the quartz-pyrite-chalcopyrite veinlets, as much as $3.09 \mathrm{ppm} \mathrm{Au}$ was detected.

The Abano mineral occurrence (locality \# 4 ; Fig. 3 ) is exposed on the southern slope along the road connecting Kakheti with the Tusheti Pass, at an altitude of 2500-2700 m. Mineralization is localized in a wide shear zone, generally following the Caucasian trend and is hosted in Toarcian sandstones and shales within a 700-m-thick section with 12 discordant mineralized zones, which range from $0.8-12.5 \mathrm{~m}$ in thickness; these zones are traced for distances of between 250 and $1400 \mathrm{~m}$ (Kuchava et al., 1983). The zones are intensely brecciated and weathered on the surface and mineralization is represented by galena, sphalerite, chalcopyrite, pyrite, and locally marcasite as veinlets, disseminations, small pods and lenses. Secondary minerals 
that can be observed include anglesite, cerussite, and locally malachite. The mineralization is very irregularly distributed with sulfide-rich and barren areas showing sharp contrasts.

One of the Abano mineralized zones, with a thickness of $2.8 \mathrm{~m}$, was studied by us in detail. The zone is dominated by abundant silicified and carbonatized shale gouge, where pyrite-galena-sphalerite mineralization is well developed. The sulfides occur as massive lenses, pods, veins, or disseminations. Our analytical results for 32 samples indicated anomalies of $252-786 \mathrm{ppm} \mathrm{Cu}, 1.78-4.41 \% \mathrm{~Pb}, 3.43$ 4.41\% Zn, 15.8- 30.9\% Fe, 35 -397 ppm As, 7 - 21 ppm Ag, and no Au.

The Lechuri mineral occurrence (Lolacity \# 6; Fig. 3) is located south of the village of Lechuri, approximately $1.5 \mathrm{~km}$ up a tributary of the Stori River, where we observed pyrite-polymetallic mineralization about $2 \mathrm{~m}$ above rocky cornices in the riverbed. This occurrence is covered by alluvial-colluvial deposits that makes it difficult to both trace the mineralization for any considerable distance or to estimate thickness. The SE slopes of the valley expose shales that are hydrothermally altered to quartz-chlorite-sericite assemblages and these in turn are are cut by sulfide-rich quartz veins of various orientations. A discordant altered zone of about 22-25 $\mathrm{m}$ in thickness can be traced approximately for more than $1 \mathrm{~km}$ along strike, with a dip of $20-25^{\circ}$, and it is localized within the Toarcian shales and sandstones.

Six samples were taken from massive sulfide mineralization and four from sulfide-bearing quartz veins from the Lechuri occurrence. Results from the ICP-MS analyses of the massive sulfide showed 2080 ppb Au, 5 - 16 ppm Ag, 40 - 292 ppm As, 7 - 28 ppm Bi, 9 - 26 ppm Cd, 7 - 21 ppm Co, 300 - 1470 ppm Cu, 1850 ppm - >1\% Pb, and $3380 \mathrm{ppm}->1 \% \mathrm{Zn}$. Metal concentrations are similar for the quartz-sulfide veins and average $80 \mathrm{ppb} \mathrm{Au}, 5 \mathrm{ppm} \mathrm{Ag}, 292 \mathrm{ppm}$ As, 9 ppm Bi, 9 ppm Cd, 7 ppm Co, 696 ppm Cu, 9010 ppm Pb, and $\mathrm{Zn}>1 \%$. According to the geochemical signature, mineralization style, and geotectonic setting, the Lechuri mineral occurrence shows similarities to the well-studied Filizchay pyrite-polymetalic deposit located on trend and across the border in Azerbaijan (Mustafaev et al., 2006); this proximity of a large metal deposit emphasizes the importance of further research at Lechuri.

The Tebulo district is located in Tusheti (Locality \# 1; Fig 3), on the southern slope of Tebulo Mountain, at 2700-2900 m altitude and covering about $22 \mathrm{~km}^{2}$ in area. According to toponym the area is referred to as an "ore throat" in the Tush dialect, which means "ore place". The metal-bearing rocks are mainly Pliensbachian terrigenous sediments, which are intruded by gabbro-diabase and diorite bodies. The area is located at the intersection of the Caucasian and Transcaucasian regional deep faults, which makes the district highly prospective. Sedimentary rocks form an overturned NW-SE, $135^{\circ}$ striking anticline facing south and dipping $70^{\circ}$ '! $45^{\circ}$ while a 220 m-thick steeply dipping brecciated zone with a strike of $175^{\circ}$ and dip direction of $75^{\circ}$ ! $85^{\circ}$ cuts the anticline .

The small ridge situated in the central part of the Tebulo district divides the area into two parts. In the western part, on the northwestern slope of the Dakvekhis-Khevi River, there are eight parallel mineralized bodies exposed. They are hosted by gouge in silicified shales and consist of quartz-, pyrite-, chalcopyrite-, and galena-bearing veinlets. The thickness of these bodies varies from $1.5-6 \mathrm{~m}$, and each is separated by layers of brecciated shales, cumulatively forming a zone as thick as $35 \mathrm{~m}$. The 48 samples from the mineralized zone were analyzed at the laboratory of CMG Gold Ltd. The analyses showed $0.1-2.10 \% \mathrm{Cu}, 0.01-0.92 \% \mathrm{~Pb}, 0.01-0.98 \% \mathrm{Zn}$, and $4.0-$ $21.1 \mathrm{ppm} \mathrm{Ag}$. Gold was detected in almost all samples at concentrations ranging from $30-640 \mathrm{ppb}$ indicating some precious metal potential for the western part of the Tebulo district.

In the eastern part of the Tebulo district, highly crushed, brecciated, and silicified shales are found in the rocky cornices on the southeastern side of Tebulo Mountain: these are pervasively altered to quartzsericite-chlorite, an assemblage typically noted on the top of porphyry deposits. From the base of the cornices, for 250-300 m downward, on the northwestern slope of Tebulo River, copper-rich polymetallic mineralization is found in a vein of 1.3-1.7 $\mathrm{m}$ in thickness outcrops. The extent of veining is difficult to judge because of rock slides covering some of the area. Large mineralized boulders, $1 .-1.5 \mathrm{~m}^{3}$ in size, eroded from these veins are present in several places on the valley floor. Fourteen samples of massive pyrite-polymetallic mineralization from the Tebulo occurrences were analyzed by ICPMS. The results showed $500-725 \mathrm{ppm} \mathrm{Cu}, 1300-1430 \mathrm{ppm} \mathrm{Pb}$, and $>1 \% \mathrm{Zn}$ in all samples. Average concentrations of other elements included 25.3 -30.9\% Fe, 452.3-745.4 ppm Cd, 82.8146.7 ppm Co, 72.3 -81.9 ppm Bi, 56- 721 ppm Mn, 18.4-21.7 ppm $\mathrm{Ni}$, and 178.8-219.0 ppm As. Silver and gold were detected in all samples, with reported ranges of 8.19 - $10.57 \mathrm{ppm} \mathrm{Ag}$ and the 29$141 \mathrm{ppb}$ Au.

\section{Discussion and Conclusions}

The field work we have carried out has showen that the eastern Greater Caucasus in Georgia generally comprises intensely folded and overturned-to-the-south Lower-Middle Jurassic shales, sandstones, and thick volcanogenic-sedimentary series. They follow the general Caucasian trend and can be traced far to the southeast and northwest. The geological data all suggest that the entire rock sequence accumulated within a marginal sea environment during a period of extenstion and destruction of Paleozoic basement.

The study has also shown that throughout much of the late Mesozoic evolution of the eastern Caucasus in Georgia intense magmatic processes took place. Evaluation of all data indicates that three stages of magmatic activity occurred. The first magmatic activity was related to extension and subsidence in the Early Jurassic, when rhyolitic, through dacitic, and to andesitic-basaltic magma was formed through progressive fractional crystallization. The second important episode of magmatic activity was related to extension of newly formed crust and is characterized by Bajocian-aged (170-168 ma) basic intrusions emplaced into Lower Jurassic-Aalenian sediments and a dike system of gabbro-diabase was widely implaced. The third magmatic event is associated with folding and uplifting during which multiphase dioritic plutons and associated felsic diferentiates (168-166 MA) intruded into the sedimentary rocks and caused widespread hydrothermal alteration, including development of propylitic and phyllic assemblages, and associated sulfide mineralization.

Our metallogenic research has shown that a wide range of mineral occurrences, largely in terms of composition and style, is represented within our study area. Most of the occurrences we investigated are only locally exposed in drainages. We believe that the potential for finding important resources at shallower depths is high, particularly under the cover of sedimentary formations and where altered zones 
are exposed at the surface. According to a number of parameters many of these mineral occurances are likely to be genetically linked to largely blind but potentially productive magmatic centers (Ridley, 2013).

The zones of non-ferrous base metal occurrences are separated, in the eastern Greater Caucasus region, into southern and northern sectors as in Kharashvili (1964) and Akimidze et al. (1980). According to these workers, the southern zone hosts chalcopyrite-pyrrhotite occurrences (e.g. Samchedlo, Englisuri, Katsdag), whereas the northern one hosts metal sulfides (pyrite, sphalerite and galena) occurrences (e.g., Abano, Ilurta, Tebulo). They believed that formation of the different types of occurrence caused by different hydrothermal fluid sources and report that the chalcopyrite-pyrrhotite occurrences were genetically linked to basic and intermediate magmatism, and the pyrite-polymetallic occurences were associated with felsic magmatic activity (Bogdanov, Kutyrev, 1973). Fieldwork conducted by us, in contrast, strongly suggests that the sulfide composition of hydrothermal occurrences reflects the distance between the causative magmatic center and the site of mineralization. As numerous experiments have shown (e.g., Cramanske and Rye, 2008; Okomato et al., 2010), for a hydrothermal fluid of a distinct composition and under a single pressure regime, chalcopyrite precipitation will take place at temperatures that are about $100^{\circ} \mathrm{C}$ higher than those for sphalerite and galena precipitation. We believe that the same hydrothermal fluid closer to a magmatic center will generally deposit chalcopyrite but when it travels farther away, sphalerite-galena bodies will preferentially form.

Thus, from the conclusions of our metallogenic research, it can be seen that numerous mineral occurrences in the Georgian segment of the eastern Greater Caucasus region formed from similar magmatichydrothermal fluids, but under different temperature regimes. There is no doubt that Artana, Loduani, Chelti, and other similar mineral occurrences are small-scale when compared to many developed worldclass metal deposits. However, we believe the Stori and Tebulo districts have potential for development of large-scale resources, as supported by the extensive development of quartz-sericite-chlorite-pyrite and albite-epidote-chlorite-pyrite alteration zones that typically are characteristic of porphyry deposits.

The Lechuri mineral occurrence, which was discovered during this research, is of great interest. The mineralization shows important similarities to the Filizchay pyrite-polymetallic deposit based on geology, mineralogy, and geochemistry. Because of this, it is necessary that further detailed study of the mineralization should be conducted. This present research has noted for the first time the presence of elevated concentrations of gold in the region. It should be noted that in the Tebulo district, where gold anomalies were determined in massive polymetallic bodies, is associated with strongly silicified zones, which is an important result of our research.

In conclusion, we note that it is necessary to undertake more detailed metallogenic research in the eastern Greater Caucasus Georgian segment in the future, because many significant problems still exist and important ore deposits, similar to those in neighboring Azerbaijan and Dagestan may be present, but concealed by areas of shallow cover.

\section{Acknowledgements}

The authors would like to thank the Rustaveli National Science Foundation of Georgia for funding the project (\#GNSF/ST09-1071-
5-150) through which the research work was conducted in the eastern Greater Caucasus. Special thanks to Prof. Richard J. Goldfarb (USA) and Robert G. Blair, Consulting Economic Geologist (USA), for their valuable advices and comments, and editorial input that helped improve the presentation of the paper.

\section{References}

Akimidze, K., Benidze, G., Fruidze, M. 1980, Prospecting works for 1975 1980yy, 1:25000 scale, within the copper-pyrrhotitic belt of Kakheti in the interfluve of the rr. Lopota-Alazani. Funds of Geological Department of Georgian SSR: Report, 235 p.

Akimidze, K., 2010, Late Pliensbachian-Early Toarcian Volcanism of TransAlazani Kakheti. In proceedings of the Al. Janelidze Institute of Geology, New Series, v.125, pp. 164-172.

Bogdanov, Y.V, Kutyrev, E. I., 1973, Classification of Stratified Copper and Lead-Zinc Deposits and the Regularities of Their Distribution. In: "Ore in Sediment", International Union of Geological Sciences, v. 3, pp. 5563.

Cramanske, G., Rye, R., 2008, Experimentally Determined Sulfur Isotope Fractionations between Sphalerte and Galena in Temperatute Gange 600 degrees to $275^{\circ} \mathrm{C}$. Cosmochim. Acta, v. 50, pp. 651-662.

Gamkrelidze, I., P., 1997, Terranes of the Caucasus and adjacent areas. Bull.Academy of Sciences Georgia ,v. 4(3), pp. 75-81.

Gamkrelidze, I. P., 1986, Geodinamic evolution of the Caucasus and adjacent areas in Alpine time. Tectonophysics, v. 127, pp. 261-277.

Kekelia, S., Kekelia, M., Otkhmezuri Z., Özgur, N., Moon, Ch., 2004, Oreforming systems in volcanogenic-sedimentary sequences by the example of base metal deposits of the Caucasus and East Pontic metallotec. Bulletin Mineral Research Exploration v. 129, pp. 1-16.

Kharashvili, G. I., 1964, Copper-pirrhotitic ore formation of the Greater Caucasus. Bull. Georg. Acad. Sci.,v. 7, no.3, pp. 36-45.

Kuchava, E., Melikishvili, T., Benidze, G., 1983, Report on General Prospecting Works Results for 1980-83 yy, 1:25000 scale, in the northern part of Lower-Upper Jurassic formations of the interfluve of the rr. Chelti-Alazani. Funds of Geologic Department of Georgian SSR, Report, $214 \mathrm{p}$.

Mustafaev, G. B., Velzade, C. F., Efendieva E. H., 2006, Geological-Genetic models of pyrite ore deposits of Azerbaijan. Report of Azerbaijan National Academy of Sciences, no. 4. pp. 12-23.

Okamoto, A., Saishu, H., Hirano, N., Tsuchiya, N., 2010, Mineralogical and textural variation of silica in hydrothermal flow-through experiments: Geochimica et Cosmochimica Acta v.74, pp. 3693-3706.

Okrostsvaridze, A., Tormay, D., 2013, Phanerozoic Continental Crust Evolution of the Inner Caucasian Microplate: The Dzirula Massif. Episodes, v. 36, no.1, pp. 31-39.

Okrostsvaridze, A., Akimidze, K., Bluasvili, D., 2012, The First Data on Industrial Concentration of Thorium and Bismuth in Hydrothermally Altered rocks of the Stori Canyon (Greater Caucasus). Bull. Georg. Acad. Sci. v. 5, no. 2, pp. 76-82.

Philip, H., Cisternas, A., Gvishiani, A., Gorshkov, A., 1989, The Caucasus: An actual example of the initial stages of a continental collision. Tectonophysics, v. 161,pp. 1-21.

Rebaï, S., Philip, H., Dorbath, L., Borissoff, B., Haessler, H., Cisternas, A., 1993, Active tectonics in the Lesser Caucasus: Coexistence of compressive and extensional structures. Tectonics v. 12, pp. 1089-1114.

Ridley, J., 2013, Ore deposit geology. Cambridge University Press, London, $398 \mathrm{p}$.

Staatz, M. N., 1974, Thorium Veins in the United States. J. Econ Geology, v. 69, pp. 494-507.

Topchishvili, M., 1996, Stratigraphy of Lower Jurassic Formations of Georgia. Bulletin of Academy of Science Georgia, New Series, v.108, 216 p. 


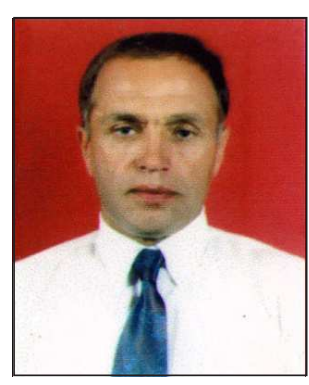

Avtandil Okrostsvaridze received his degree of Doctor of Geological Sciences in 1995 from the Geological Institute of the Georgian Academy of Sciences. His main scientific interests comprise magmatism of orogenic systems and ore mineralization processes related to them, and; mantle-crust interaction and continental crust evolution; natural hazard estimation and geological enviroment influence on human health. At present he works as a professor of Ilia state University and as a scientific supervisor at the mining corporaion "Golden Fleece".

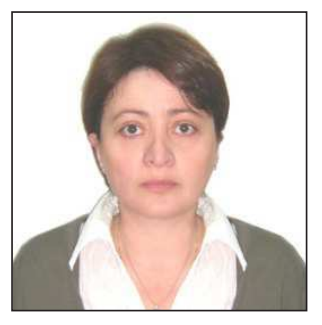

Ms. Nona Gagnidze graduated with a M.Sc. degree in Geological Sciences from the Tbilisi State University. She is currently a PhD student at the faculty of Engineering, Ilia State University. Her main scientific interests include sedimentary and volcanicsedimentary stratigraphy, Cretaceous and Paleogene sedimentary basin evolution of the southern slope of the Greater Caucasus; and mineral deposit genesis and their anomalies. She has conducted a number of international collaborations with colleagues at the U.S. Geological Survey.

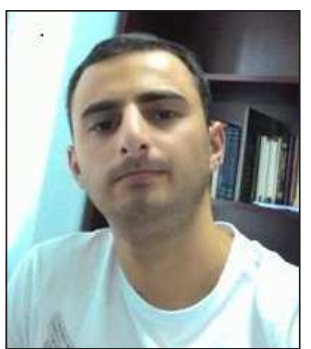

Giorgi Boichenko works as a geologist at the Institute of Earth Sciences at the Ilia State University. He obtained his bachelor's degree in geology from Tbilisi State University in 2009 and his master's degree from Ilia State University in 2012. His main interest in geosciences is the structural geology and neotectonics. 